\title{
To What Inanimate Matter Are We Most Closely Related and Does the Origin of Life Harbor Meaning?
}

\author{
William F. Martin *(D), Falk S. P. Nagies (D) and Andrey do Nascimento Vieira \\ Department of Biology, Institute for Molecular Evolution, Heinrich-Heine-Universität Düsseldorf, \\ 40225 Düsseldorf, Germany; falk.nagies@hhu.de (F.S.P.N.); nascima@uni-duesseldorf.de (A.d.N.V.) \\ * Correspondence: bill@hhu.de
}

Citation: Martin, W.F.; Nagies, F.S.P.; do Nascimento Vieira, A. To What Inanimate Matter Are We Most Closely Related and Does the Origin of Life Harbor Meaning? Philosophies 2021, 6, 33. https://doi.org/10.3390/ philosophies6020033

Academic Editor:

Rainer Zimmermann

Received: 4 March 2021

Accepted: 12 April 2021

Published: 15 April 2021

Publisher's Note: MDPI stays neutral with regard to jurisdictional claims in published maps and institutional affiliations.

Copyright: (c) 2021 by the authors. Licensee MDPI, Basel, Switzerland. This article is an open access article distributed under the terms and conditions of the Creative Commons Attribution (CC BY) license (https:// creativecommons.org/licenses/by/ $4.0 /)$.

\begin{abstract}
The question concerning the meaning of life is important, but it immediately confronts the present authors with insurmountable obstacles from a philosophical standpoint, as it would require us to define not only what we hold to be life, but what we hold to be meaning in addition, requiring us to do both in a properly researched context. We unconditionally surrender to that challenge. Instead, we offer a vernacular, armchair approach to life's origin and meaning, with some layman's thoughts on the meaning of origins as viewed from the biologist's standpoint. One can observe that biologists generally approach the concept of biological meaning in the context of evolution. This is the basis for the broad resonance behind Dobzhansky's appraisal that "Nothing in biology makes sense except in the light of evolution". Biologists try to understand living things in the historical context of how they arose, without giving much thought to the definition of what life or living things are, which for a biologist is usually not an interesting question in the practical context of daily dealings with organisms. Do humans generally understand life's meaning in the context of history? If we consider the problem of life's origin, the question of what constitutes a living thing becomes somewhat more acute for the biologist, though not more answerable, because it is inescapable that there was a time when there were no organisms on Earth, followed by a time when there were, the latter time having persisted in continuity to the present. This raises the question of where, in that transition, chemicals on Earth became alive, requiring, in turn, a set of premises for how life arose in order to conceptualize the problem in relation to organisms we know today, including ourselves, which brings us to the point of this paper: In the same way that cultural narratives for origins always start with a setting, scientific narratives for origins also always start with a setting, a place on Earth or elsewhere where we can imagine what happened for the sake of structuring both the problem and the narrative for its solution. This raises the question of whether scientific origins settings convey meaning to humans in that they suggest to us from what kind of place and what kinds of chemicals we are descended, that is, to which inanimate things we are most closely related.
\end{abstract}

Keywords: origins of life; epistemology; hydrothermal vents; warm little pond; site of life's origin

\section{Introduction}

The question of how life emerged is older than science. Historically, various cultures have found satisfactory explanations for how life emerged. Such explanations have been and continue to be of great importance both to society as a whole and to individual members thereof. We will make no attempt to present the origins narratives of different cultures here; every reader will know some examples against which to vet the merit of our claim. The explanations that different cultures have handed down over generations differ in their principles and narrative, though all fulfil a common goal of providing an account of how living things in general and humans in particular fit into the continuum of time. Scientists also have explanations for how life emerged. The explanations that different scientists offer also differ in their principles and narrative, although it is unclear whether scientific origins narratives generally provide an account of how humans fit into 
the continuum of time, because most scientific origins narratives do not directly connect to specific kinds of living cells that we can observe today that could serve as a starting point of biological evolution. That is, most scientific origins narratives either offer an account of an abstract or idealized cell or, more often, strive to explain some specific aspect or individual component of cells, rather than addressing the origin of the whole cell. For example, many origins narratives present an account for where RNA came from and what it can do if one assumes the existence of an unlimited supply of activated RNA precursors on the face of the early Earth $[1,2]$. That is a much simpler task than presenting a narrative for where a whole living cell came from under the premise that there was no unlimited supply of activated RNA precursors anywhere on the early Earth [3,4]. RNA is a molecule: a nucleic acid with three simple components-phosphate, sugar, and bases-that are iterated in a linear polymer that can assume different conformations via folding. It is easier to explain the origin of a molecule than it is to explain the origin of a prokaryotic cell: a small volume of space roughly one micrometer on a side, containing about ten thousand ribosomes, each consisting of about $50 \%$ RNA by weight, plus five million individual protein molecules that catalyze on the order of 2000 different chemical reactions that harness environmentally available energy and nutrients to make an imperfect copy of itself in a period of time that might last $20 \mathrm{~min}$ or 2000 years. It is also unclear whether scientific origins narratives, whether for molecules or cells, even qualify as science, because the object of investigation lies irretrievably buried in the past, such that even if we were to recreate life from chemicals in a laboratory, we would have no way of ascertaining whether the first cells, our ancestors, arose that way.

Should we then just give up on studying origins? There are good reasons to do so, but at the same time, humans apparently have an innate curiosity about where we came from and how living things came to be the way that we observe them to be in nature. It is part of our human condition to seek and find answers to the question of where we came from. This might relate to the circumstance that humans seem to generally fear things that they cannot explain and tend to find comfort in explanations of otherwise inexplicable phenomena. Scientific narratives for origins do not provide comfort, though they do strive to soothe our curiosity about the living past. The interest of the general public in origins would, of itself, seem to justify origins research.

During the Enlightenment, European science sought independence from religious doctrines, but its scientific revolution had no immediate impact on scientific concepts about origins because that first generation of people whom we would tend to call scientists by today's measures, while taking a pragmatic rather than dogmatic approach to natural phenomena, had no grasp whatsoever of what makes living things alive and what they are made of, let alone how such might have arisen. Priestly's discovery of oxygen [5] was a step towards identifying chemical requirements for life, but offered little help towards understanding what living things are or where they come from.

Though today's libraries can boast much progress in organic chemistry, microbiology, geoscience, astrobiology, and computational biology, the question of how life began remains perennially near the top of the ten most wanted list of major (and underdetermined) problems or questions facing science. Traditional approaches to the problem start from the simple and work forward to the complex. If we place the origins problem in the context of chemistry that was known around 1900, scientists knew that atoms form molecules and that cells contain molecules, though most of the molecules were too large and complex to identify. Scientists knew that cells transform substrates into other molecules in some manner, but the nature of such transformations was obscure, as was the question of whether any chemical transformations were universal among cells. Otto Warburg helped to unravel a good many of the chemical transformations germane to the reactions that keep cells alive $[6,7]$. Today, we know a great deal about how cells transform molecules during the process of growth (physiology, the chemical reactions of growth) and how the information that directs the synthesis of a new cell is stored and retrieved, but the origins problem of how such reactions started remains, although some newer findings do harbor hints of 
progress in that they identify a distinct chemical connection between geochemical reactions and what might have been the first biochemical reactions [8,9].

Tracking down the first chemical reactions that led to metabolic pathways would allow us to pin a starting point on the map of physiological reactions. If we had a robust clue about the starting point of metabolism, we could probe the concept further by experiment. However, if we consult the literature about the myriad ways in which cells make a living physiology, the undertaking of assigning a starting point might seem like a task without chance of success. There are hundreds of biochemical pathways used by countless prokaryotic lineages, many with unique traits, and most microbes that we know to exist (because we can see them) are still vastly under characterized because they do not (yet) grow in pure culture. But is the search for a starting point of physiology really futile? Among all the pathways we know, whereby hundreds are used for harvesting energy alone [10], common sense has it that they cannot all be equally old. Some pathways must be older and some must be younger. They cannot all have arisen at once. There must have been a temporal progression in metabolic evolution [11]. Finding a suitable starting point for the evolution of biochemical reactions would help constrain an otherwise unwieldy problem, because it would identify the chemical reactions at the very base of the life process as it arose.

Given the daunting diversity of microbial metabolism, finding its starting point appears as a typical needle in a haystack problem: hopeless. However, let us suppose that the needle really is in the haystack, that is, that among the thousands of pathways we know, one really is the oldest. To find it, all we have to do is use a really strong magnet, and suddenly, finding that needle is easy, a day's work for one person-with that we can identify the starting point of metabolism, the origin of the chemical reactions that produce cells. Where can we obtain such a magnet? We will return to that at the end of this paper.

\subsection{Narratives Are Set in Places}

In recent years, rapid progress in the field of genome sequencing and analytical biogeochemistry has enabled the creation of robust molecular libraries that allow a far more precise categorical classification of life forms than anything we had previously. In the past however, many of these categorizations were performed via generalization derived from complex and systematic observation of macroscopic animals and their traits over many generations in a populational context. In most cases, evolutionary experiments were not feasible. In the 1800s, the rise of evolution as a theory changed everything about the way scientists thought about the history of life, and brought with it the possibility of a single origin from which all else might have emerged via time and change. Though no one in Darwin's time could have provided a satisfactory answer to the fundamental problem of origins, his speculations on the first organism's environment, the "warm little pond" in his correspondence with Hooker, paved the way to the proposal of the first concrete experiments in the field many decades later [12]. Darwin left a hint about the conundrum of origins in a time where geochemical data for the deep past were scarce, if not completely unavailable. Still today, the answers to origins are buried irretrievably deep in the past. In Darwin's day, no experimental approach was robust enough to spark progress on the issue, thus leaving most hypotheses to the sheer taste of personal belief systems. To some extent, that is still true today.

Darwin set a rarely recognized tradition in origins research; he started the origins narrative exactly the same way as traditional cultural and religious narratives usually have, namely he started with a place and a setting, a warm little pond: "But if (\& oh what a big if) we could conceive in some warm little pond with all sorts of ammonia \& phosphoric salts,-light, heat, electricity \&c. present, that a protein compound was chemically formed, ready to undergo still more complex changes ... " [13]. Curiously, origins research still works that way today in that scientific origins narratives usually start with a place.

Of course, it would have helped Darwin to know more about the chemical reactions of cells. In his day, the most severe impediment to approaching origins in concrete language was a lack of knowledge about what cells are made of in detail and how they work as a 
chemical reaction. In Darwin's day and well into the 20th century, biologists relied on the concept of protoplasm to explain the seemingly inexplicable properties of life [14]. The term protoplasm traces to the middle of the 1800s and the Czech physiologist Jan E. Purkinje and the German physiologist Hugo von Mohl [14,15]. At the heart of the protoplasm concept was the notion that a special vital force, a vis vitalis, is associated with living substances but is lacking in non-living substances, creating, in essence, two different kinds of matter. Strong proponents of protoplasm were called vitalists, their opponents were called mechanists [16]. In Darwin's time and thereafter, biologists had no chemical understanding of the life process within cells. Vitalists held that protoplasm represented a special kind or organization of matter that bestows the property of life and distinguishes living from non-living things. In his book on protoplasm, Drysdale [17] characterized protoplasm as follows "... the elements are in a state of combination not to be called chemical at all in the ordinary sense, but one which is utterly sui generis. That, in fact, no albumin, fibrin, myosin, protagon, or fats exist at all in the living matter, but that the sum of the elements of all these is united into a compound, for which we have no chemical name, and the complex mode in which the atoms are combined we can form no idea; and it is only at the moment of death that those chemical compounds, with which we are familiar, take their origin. [ ... ] Vitality is thus a property inherent in each particle of the living matter, and all the parts of a complex organism differ in function, each part has a specific kind of vitality peculiar to itself." Clearly, if one held that life was chemically distinct from other forms of matter, then the key to understanding the origin of life was understanding the origin of protoplasm, a substance immune to direct investigation, but whose properties, in theory, remained stable enough over the eons of life's history to distinguish major lineages in the living world [18]. Protoplasm might be seen as a kind of dialectic capitulation before the severity of the origins problem-its nature is too complex, hence unknowable.

Despite a lack of understanding of what cells are and how they function, and despite the absence of an empirically supported concept of the conditions on early Earth, Mereschkowsky [18] inferred that the first cells arose as the young Earth was still hot and covered in boiling water. Like Darwin, he had a setting, but it was much harsher than a warm little pond, because he thought the first cells must have been extremophiles. In his view, they were extremely small, they could thrive at temperatures of $100{ }^{\circ} \mathrm{C}$, they were anaerobes, they had the ability to synthesize proteins and carbohydrates from inorganic substances without the help of chlorophyll and they were resilient against alkaline solutions, concentrated salt solutions, sulfur compounds, and diverse toxins [18]. Those extreme conditions sound much like those of modern theories for an autotrophic origin of life in hydrothermal vents, theories that we can find in modern college textbooks [19]. Haeckel [20] espoused similar but much less detailed thoughts about the nature of the first cells. However, even today, the thought of origins in a dark, deep, hot and oxygen-free abyss, from gasses that react all by themselves in the presence of catalysts [9], conjures a hellish notion that has almost a demonic character for proponents of the warm little pond [21].

By the time of Oparin's book [12], and by Miller's [22] experiment at the latest, biological and microbiological renderings of origins gave way to chemical renderings of origins; beginnings from $\mathrm{CO}_{2}$ gave way to beginnings in some form of pond. For the majority of the last century, Darwin's hypothesis, enriched by Oparin's [12] lengthy book and Haldane's [23] tersely argued narrative of a prebiotic broth, or organic soup, inspired many researchers to embrace a simple explanation to origins: The action of sunlight on carbon in the ocean could, in principle, generate all sorts of organics, which could somehow assemble themselves in solution into something more complex. This approach assumed that at the early stages of planetary evolution, Earth's atmosphere was poor in oxygen $\left(\mathrm{O}_{2}\right)$ but rich in reducing gasses such as ammonia $\left(\mathrm{NH}_{3}\right)$, methane $\left(\mathrm{CH}_{4}\right)$, and hydrogen $\left(\mathrm{H}_{2}\right)$, based on studies of other planetary bodies like the outer Jovian planets in our solar system. This kind of atmosphere, which was used in Miller's experiment, generated amino acids and other organics using energy supplied by an electric spark, simulating lightning. 
Many subsequent hypotheses built upon this foundation, adhering to the premise that, in essence, the origins problem consisted of two components: an initial process or phase of molecular synthesis to obtain the basic building blocks of life (the origin of soup) in a particular setting, followed by a subsequent process or phase of molecular organization that arranged pre-existing components into more highly structured state (self-organization). In the 1970s, a concept emerged that RNA molecules could compete with one another for activated RNA monomers (resources), such that the fastest replicating molecules became the most fit in a Darwinian sense [24] by bringing forth the most progeny. This idea was exceptionally well suited to empirical endeavor and experimental tests. It gave rise to over five decades of productive research on a concept and a field that have become widely known as the RNA world. In many modern papers, one can read about the RNA world as if it were an established "fact", a known whose properties merely require further characterization [1]. In other papers, the term RNA world is used more or less synonymously with the origins of life [25]. There is now much evidence underpinning the view that RNA molecules can multiply if they are provided with a steady stream of biochemically pure precursors, so much evidence in fact that some have begun to ponder the "ecology" of RNA molecules in such a world [1] as if it, the RNA world, were an observation in nature as opposed to a premise.

Fascination with RNA has, however, distracted from the more important and still unanswered question of whether an RNA world ever existed and if it existed [26,27], whether it had anything to do with the origin of things that are actually alive-microbial cells [28]—notwithstanding the sobering observation that RNA, given inorganic substrates, is clearly no more alive than an isolated protein, a fat droplet, or a grain of starch. A critic will immediately interject that we are constraining the issue too much by imposing the criterion of living from "inorganic substrates", but if we accept the evidence indicating that the moon forming impact converted the Earth to a ball of boiling magma, converting all carbon to $\mathrm{CO}_{2}$, then $\mathrm{CO}_{2}$ was the initial form of carbon from which life emerged [29]. Another critic will complain that after the magma oceans cooled, there was a late heavy bombardment that brought a veneer of new organics from space, countering the $\mathrm{CO}_{2}$ dictum [30]. We would counter that the late heavy bombardment probably never even occurred; it is more likely an artefact of (mis)interpreting lunar craters [31]. Another critic might complain that we are countering philosophical critique with appeals to evidence rather than logic. Yes, as we said at the outset, this is an informal essay about origins and meaning.

\subsection{Molecules or Cells?}

For the biologist, it is sometimes more useful to discuss the origin of "microbial cells" than to discuss the origin of "life" because if one debates the origin of life, one can debate in very open terms and with a long literature the question of what life is, leading to philosophically fertile but biologically barren fields of discourse. If we constrain the issue to concern the origin of things that are obviously alive, microbial cells, and without whose existence there would be no creatures that debate, then we get closer to the issue, the dimension of which causes many researchers to give up: how do we get from the early Earth to a fully fledged free living microbial cell whose main function it is to first convert environmental energy into expendable chemical currency for survival and then, if resources permit, to grow from inorganic compounds all by itself. The hard part of seeing the origin of life as the origin of microbes is that one first has to learn a lot of biology, the nuts and bolts of what cells are and how they work, so as to be able to verbalize specific processes underpinning the origins of the components and the whole. That is why it is much more convenient to reduce the origins problem to the origin of RNA, which is a very simple explanandum compared to a cell, or to detour into definitions of life where there are almost no constraints in observation to guide our reasoning. If we insist on defining the problem as the origin of microbes, we can get straight to work on that problem without having to debate the existence of an RNA world or define life before starting. Solving the problem 
of the origin of microbes would then be left up to biologists, where it arguably belongs (and where it began), because (with pro domo immodesty) nobody knows the individual chemical reactions that compose living things and the $\sim 2000$ enzymes that catalyze those reactions in a given microbial cell better than biologists.

We also face the problem that the origin of microbes was a singular event by all logic, because of the universality of central metabolism [32] and the universality of the genetic code [33], and that origin event occurred roughly 4 billion years ago according to isotope data [34]. Again, even if we performed an experiment in which microbial cells demonstrably arose de novo from inorganic compounds in a laboratory experiment, we would still have no evidence in hand that life (our unicellular microbial ancestors) actually arose that way, we would just have a narrative richer than our current ones on how it might have occurred. A priori, we have no access to a more systematic approach to natural problems than of hypothesis, experimentation, observation and interpretation. It seems clear that we can use the scientific method to explore aspects related to the origins problem, but the problem might be without solution. No final answers to be had at origins? That would be an honest admission, but it would not satisfy the curiosity of scientists and the public when it comes to wanting to know where we come from. It is part of our human nature to want to know about the past. All human cultures have a natural interest in the question of where living things came from, a question that, in contrast to agriculture or medicine, has no obvious practical importance unless, of course, concepts of origins help provide meaning, and meaning simultaneously has practical importance, a question that is well beyond the scope of this paper.

If we want to probe problems rooted deep in the past, such as the emergence of the first prokaryotic cells and the diversification of primordial prokaryotic lineages some 4 billion years ago, we have to make some assumptions for the sake of moving forward, and we have to state the assumptions explicitly. Darwin started in a pond, but he never justified why he chose to start in a pond. There might be several ways to recreate life in the laboratory, but the universal laws of thermodynamics that govern the chemical reaction that we call biology apply across the tree of all life. All cells require proteins that are made of amino acids; cells are about $50 \%$ protein by dry weight. Genetic material is made of nucleotides; cells are about $20 \%$ RNA and 3\% DNA by dry weight [35]. Cells require a constant far from the equilibrium system from which to harness energy; cells always synthesize much more ATP than they need, often three times more [36,37], because ATP is the main energy currency of the cell and the converse would violate the 2nd law of thermodynamics. Armed with a few observations of this type, we can discuss the origins problem in the comfort that we are just thinking about it, not trying to solve it.

\subsection{Teleology and the Notion of Epistemological Obstacles}

Epistemology (the theory of knowledge, the methods to obtain knowledge, and the scope of knowledge) is generally traced to ancient Greece with the works of Plato and Aristotle, who pondered what we know and the distinction between what exists and what does not. In the seventeenth century, John Locke's philosophic categorization and understanding of knowledge became a branch discipline of philosophy per se. Gaston Bachelard [38] contextualized the fields of scientific knowledge and its intrinsic robustness and is regarded by some to be one of the founding fathers of modern epistemology [39-41]. Bachelard [38] proposed that the scientific mind must develop against human nature and that epistemological obstacles are natural stressing points to scientific knowledge that hinders scientific progress. He proposed obstacle categories that have affected science. These include the first experience, or how the first object of research can establish a bias for further experiments, leading to mischaracterization of the subject of study. This can snowball to generate a premature generalization of the problem, another obstacle. The limitations of natural language, the broad use of scientific terms or analogies and the restrictive nature of explanatory words can further impede understanding as can animism as an explanation to natural problems or indiscriminate use of knowledge with its often- 
overlooked teleological conception. Few scientific questions lend themselves more readily to animism and hidden teleology (the explanation of phenomena in terms of the purpose they serve rather than of the cause by which they arise) than the issue of how inorganic material became living cells.

According to Mayr [42], no other ideology influenced biology as much as teleology. Mayr categorizes the teleological obstacle into five subsections: (i) Teleonomic processes, referring to phenomena with a goal-directed purpose guided by an implicit program. (ii) Teleomatic processes that are not guided by a pre-established program but instead follow passively a directed path of events as a result of the action of natural laws [43]. (iii) Cosmic teleology refers to processes guided by a supreme force. (iv) Adaptive programs, or processes in which there is a direction of events towards a posteriori outcomes such as those observed in non-Darwinian evolutionary theories. Lastly, there is (v) purposeful behavior in which the subject of change is directing its behavior towards a certain need. Mayr proposes that the use of teleological arguments must be avoided at all costs as no phenomenon in nature is innately teleological. In Masatoshi Nei's mutation driven theory of evolution [44], teleological components are forbidden by mechanistic means, the primary process-driving vectors of evolution being mutation, which all things being equal can be (somewhat safely) assumed to be blind. As such, the use of teleology in the field of origins fuels the discussion of whether there is a role to dogma in science and if such concepts hinder the acquisition and transmission of knowledge by (falsely, we assume) giving purpose to the natural phenomena permeating chemical and biological evolution.

\subsection{Could Nei's Conjecture Be True?}

Yet before we look into stumbling blocks of how we think about evolution, let us consider something that has bothered the senior author of the present paper for some time. Is Nei right? Does mutation really set a vector in evolution [44], or is mutation unlimited in scope with selection doing the work of bringing forth new forms from the set of all possible? Worse, is there any way we can even approach an avenue towards obtaining an answer to the problem? We know more about our world than in Plato's day, maybe we can get an estimate. We start with the question of how many cells have ever lived and the estimate that roughly $10^{30}$ microbial cells are alive today [45]. Most of these cells are living in the subsurface or marine sediment where they are growing very slowly, if at all, some with doubling times estimated as hundreds or even thousands of years [46]. We generously give them fast growth and an average doubling time of ten generations per year. Ten generations (doublings) per year would mean a 1024-fold increase of $10^{30}$ microbes or $10^{33}$ new microbes per year, but global biomass cannot increase 1000-fold every year, as nutrients are limiting (fortunately, for us all). However, we are still generous and say that each microbe nonetheless manages 10 generations per year (accompanied by many microbes that simultaneously die). For $10^{30}$, microbes that gives us $10^{33}$ individual doublings per year, or, summing up across 4 billion years, we have about $4 \cdot 10^{42}$ generations on the books, which we conveniently round to $10^{42}$ new microbes in history because for most of earth's history, fewer microbes existed per year than today, owing to the lack of oxygen. How many mutations have there been in those $\sim 10^{42}$ cells? Let us say that a microbe has a mutation rate similar to that in Escherichia coli, on the order of $10^{-3}$ per generation per genome $[47,48]$. At that rate, for every 1000 cells that undergo one cell division, one new mutation will accrue. Over 4 billion years, that means that every 1000th cell gets a new mutation, or about $10^{39}$ new mutations in all of evolution. That sounds like a big number. Yet maybe we underestimated the number of cells badly, for example that we should be using much faster doubling times, so we throw in a factor of $10^{9}$ for good measure, giving a rather generous estimate of $10^{48}$ mutations that have occurred in evolution-a big number, close to the number of water molecules in the oceans, but smaller than the approximate number of protons in the universe, $\sim 10^{80}$. How does the number of roughly $10^{48}$ mutations in evolution stack up against the number of possible mutational states for microbial genomes? Are they roughly equal? 
For that, we have to estimate how many mutational states are possible. If each microbe has one genome of only 1000 genes with avg. $1000 \mathrm{bp}$ each, then there are $10^{6} \mathrm{bp}$ in the genome, with four possible bases per position, or $4^{1,000,000}$ possible sequences, which is about $10^{602,060}$, or close enough to $10^{600,000}$ to round it for our purposes. We can also count gene transfers into the mutation category, which does not generate sequence variants beyond the $10^{600,000}$, although it could increase the number of sites in the genome, raising the number of possible mutational states. The number of possible sequences that could be realized for small genomes during evolution, $\sim 10^{600,000}$, is hundreds of thousands of orders of magnitude greater than the number of mutations that took place, generously estimated at $\sim 10^{48}$. One might interject that many sequences cannot be realized because of the nature of the genetic code, the size of proteins, the occurrence of stop codons, etc. To conservatively take that into account, let us say that the structure of genes, reading frames, proteins and the genetic code constrains evolution so tightly that only one single base per gene is allowed to vary by mutation. That is an extreme exaggeration of reality, but we are just trying to get an estimate. Allowing only one base per gene to mutate per genome, keeping all other bases constant throughout evolution, reduces the number of possible sequences from $4^{1,000,000}$ to $4^{1000}$ possible sequences because we have assumed 1000 genes per genome, and that still translates to $10^{603}$ possible sequences, such that even then, the number of possible sequences, over-conservatively estimated, that could be realized for small genomes during evolution, is still $10^{500}$ times greater than the number of mutations that took place, overgenerously estimated, recalling that the number of protons in the universe is roughly $10^{80}$ for comparison.

Regardless of how we cut the cake of possibilities, mutation rules, it would seem. Does Darwin's natural selection even figure into this? Yes, in the big picture, selection is important, obviously, as it weeds out unviable sequence variants in specific environments. However, the point here is that mutation never even had a ghost of a chance to explore what combinations are possible with genomes in four billion years. Nei once said in a lecture to 1000 evolutionary biologists in Puerto Rico "Natural selection is overrated". The audience gasped, some quietly scoffed. The person sitting next to one of us (WM) asked "Did he really just say that?", "Just listen and pay attention" was the reply.

The foregoing back of the envelope calculation shows that the vectors of evolutionary lineages from origins to the present were mechanistically limited by mutation (and driven forward in time by thermodynamics, we know without the calculation). There was never a world on this planet where life explored all possibilities, with selection pruning all viable states from the set of all possible. If mutation is blind, which we generally hold to be true, then the course of evolution is only one of (for practical purposes) an infinite number of possibilities. The path that mutations, not selection, took brought us to where we are. That is possibly irrelevant to the issue of how we think about origins, early evolution, and meaning, but possibly not. Stephen J. Gould famously asked whether if we could replay the tape of evolution, a similar result would unfold. Some argue yes [49]. The foregoing indicates that the answer is a clear no, although life still has to obey the 2nd law, meaning that the finite number of chemical reactions on Earth (there are only 92 natural elements and they have $\leq 8$ oxidation states each) that can be harnessed to support life sets constraints. Is natural selection overrated? It very possibly could be, and we are hardly the first to suggest that it is so.

\subsection{The Concept of Epistemological Obstacles in Hypothesis Pervading Origins}

We can briefly consider the role of epistemological obstacles and how they influence the progress of a heavily polarized field such as origins. Given the influence of teleology in evolutionary biology, we can ask how the categories proposed by Mayr might perpetuate a dogmatic line of thought that was deeply rooted in evolutionary biology. Although abundant in the humanities, scientific case studies of epistemological obstacles in the fields of origins and early evolution are rare by comparison [50-54]. We contextualize the concept of epistemological obstacles in origins and early evolution by identifying 
teleological arguments in origins and estimating their impacts. Being biologists by training, our philosophical scope is narrow.

The year 2020 witnessed continued progress in the chemistry of origins. The gap between opinion-based to experiment-driven hypothesis laid a concrete environment for new theoretical and experimental work. However, the origins field is divided into schools with conflicting, mutually incompatible viewpoints and heated debates as to how life started. This is a sign that the problem is underdetermined, like the origin of eukaryotes [55], suggesting a role for philosophy of science to further progress. In simplistic terms, experimental work on the topic should have an explicit theoretical basis that generates predictions, that is based on robust methods, that involves the careful observation of data that lends itself to meaningful interpretation. In practice, there is no way to perform such work without personal bias. We are the product of our experience, never genuinely objective. The literature is vast and nobody knows all of it. How to even begin forming hypotheses under such suboptimal conditions? Even in the absence of knowledge, humans are blessed with curiosity. Curiosity can lead to good experimental questions, regardless of whether we have any idea of how curiosity works. Plain curiosity can work in favor of progress. In our favor also, good scientific work ethics has it that we want to do sound work that will stand the test of time, that will make a difference as science moves forward. We all know papers that had an impact on our own view of the world, papers that made a difference in how we approach scientific work. Often, we want our papers to be like those positive examples that, together with curiosity, led us down the path that we have taken. No objectivity there. Curiosity leads investigations like mutation leads evolution.

A problem is how to reduce human bias in a field like origins. Given the multitude of theories on origins, it is only natural that scientists rely on intuition, which might be driven by curiosity. Although highly subjective, it is intuition that tells us what clues to follow and which directions to pursue further. Curiosity sets a course, intuition decides among alternative paths forward. Of course, intuition is also influenced by beliefs. With the ever-growing information pool in the context of schools following mutually incompatible hypotheses, it is only human to follow the information that meshes most harmoniously with what we "think" we already "know", leading different schools in different directions, which is perhaps the best thing that can happen to a field, for if everybody in a field is following the same idea, there is little opportunity for discovery.

\subsection{Settings in Origins Theories: Where to Start?}

There are currently a number of competing hypotheses about origins that, despite their differences, have a few things in common. For example, all theories have to assume a constant supply of carbon, nitrogen, sulfur, phosphorus and trace elements as all life is made of these; hence, we can presume that the first cells were as well, such that a constant element supply was needed to replenish reserves and to permit growth. In addition, these elements had to be supplied in such a way that they could react to form covalent bonds and simple primordial molecules, which needed to become concentrated enough to react further and form more complex molecules. All the above can be achieved in a variety of ways under certain assumed primordial earth conditions, such that the assumptions concerning the early Earth and the specifics of geochemical conditions at the site of origins constitute a main criterion by which the alternative hypothesis differs. Concerning the transition from simple chemicals to systems of molecular self-organization, few hypotheses have clear concepts, help coming from network theories and concepts of autocatalysis [56,57]. The flux into and out of a steady state pool of reproducibly formed molecules (a metabolic "identity") has to be or become stable enough for them to form increasingly complex structures, ultimately seeding a process that we would describe as evolution today. This leads to roughly seven phases in origin of life hypotheses.

1. The initial setting and medium including soluble materials and catalysts;

2. Generation of organic molecules—substrates and energy; 
3. Concentration of organics;

4. Increased molecular system complexity;

5. Stable but far from equilibrium environment fostering the newly formed system;

6. Emergence of the first free living cells;

7. The lifestyle of those first cells.

The setting that one assumes for origins bears upon all other aspects of the molecular process that leads to life or components of life or cells or microbes, so it is worthwhile to look at settings and what they bring to the origins issue.

The pond. As mentioned in the introduction, the first hints of chemically driven origins came from Darwin himself. He proposed that life started as a set of molecules that changed over time to what we consider life today. This gave rise to Oparin's [12] and Haldane's [23] primordial soup concept. This hypothesis assumed that as there were no primary consumers for the first organic molecules, over time and the action of continuous synthesis, these molecules would accumulate to high concentrations in the primordial oceans while also being free to interact with each other until life emerged. A few decades later, Miller [22] experimentally demonstrated the synthesis of some basic building blocks of life by applying electric spark to a gaseous mixture in order to simulate the early atmosphere. The demonstrable synthesis of organic molecules in the Miller experiment had broad impact because it left no doubt that basic molecules of life are nothing special (in the sense of protoplasm, for example) - they can arise through simple reactions of inorganic compounds under imaginable prebiotic conditions. There was also no specific mechanism yet that could bridge the gap between simple molecules and a living, replicating and evolving system. A possible scenario was that by chance, the first gene emerged and then life began [58]. Yet, this would make the emergence so improbable that even Oparin [59] criticized the idea [60]. Nevertheless, that did not stop researchers from building upon these ideas and realizing that, at some point, simple organic molecules were probably created from gases and that over time, these molecules had to assemble into cell-like states [61].

Clay. A possible role of clay minerals in origins was proposed in 1951 by Bernal [62], according to which life could have possibly emerged from a clay matrix [60]. In this hypothesis, organics could be adsorbed into minerals, ultimately concentrating them. A first step into how the necessary concentrations for life's reactions might have been formed apart from a primordial soup. Cairns-Smith [60] then changed this idea to what can be boiled down to self-replicating crystal systems evolving by virtue of their structural changes, which is guided by the specific organic compounds they adsorb. Eventually, these clays would undergo "a genetic metamorphosis" to purely organic units of heritage and thus, life. The incorporation of clay or mineral matrices into the theory has several advantages that would be reused in several later origin of life hypotheses. Nevertheless, another problem with several assumptions on this and other hypotheses slowly became apparent. The primordial soup was deemed unrealistic if not synthesized under increasingly specific circumstances. For example, due to the equilibrium of reactions, it would be impossible for organics to accumulate in the concentrations often assumed [63,64]. This constraint prompted the postulation of drying out phases. That is, the pond is a site for chemical synthesis and then dries up to concentrate and products of synthesis so that they might react further. One round of drying is clearly not sufficient to drive the process forward, leading to the introduction of wet-dry cycles at the site of origins [65]. Several experiments showed potential to polymerize activated RNA monomers using clay matrices as condensing agents [66].

Space. Regardless of how they polymerized, life's basic molecules had to come from somewhere [67]. Besides electricity and UV light, a popular scenario began with the discovery of amino acids (albeit mostly non-proteinogenic) in meteorites [68]. This seeded the panspermia hypothesis, a relatively old idea [69], that life could travel between planets by virtue of interstellar radiation [70] or hitchhike by meteorites [71]. This, of course, did not solve the problem of how life or its basic molecules were created in the first place. 
However, it succeeded in motivating some to change the setting for origins to Mars, for example [72], using a reasoning that a few particular chemical reactions relevant to life (polymerizations) would work better in the absence of water, such that a planet with less water might be a more likely site of origin. Cells are about $90 \%$ water by weight; cells have no problem with water, they have a problem when there is not enough water.

Black smokers. With the first reports of deep-sea hydrothermal vents in [73], there was immediate discussion of the possibility that these structures played a major role in the origin of life $[74,75]$. The initial proposal was promptly criticized as the temperatures at the black smoker types of vents, the first ones discovered, were around $400{ }^{\circ} \mathrm{C}$, too hot to sustain life [76,77]. Life is able to survive and even thrive at temperatures of $110-120^{\circ} \mathrm{C}[78,79]$, but not $400{ }^{\circ} \mathrm{C}$, which left this particular hypothesis initially with few supporters. Vents, however, impacted the origins issue deeply in that a different setting for the origins problem gave rise to different paths of origins narrative development [80]. The initial focus on temperature at black smokers was unfortunate in that it distracted from the more important observation that they presented a continuously far from equilibrium chemical setting with many metals that play a role as catalysts in microbial metabolism and with many sources of chemical energy to fuel physiological reactions [75].

Volcanic iron and sulfur. In the wake of debates about black smokers, volcanic settings for origins were proposed, where minerals once again played a central role, but not in the form of clays that could absorb chemicals, rather in the form of iron sulfur minerals that performed catalytic activity [81]. As the start of metabolism, Wächtershäuser proposed a citric acid cycle that was energetically driven forward by pyrite synthesis [82]. This harkened back to the conditions proposed by Mereschkowsky [18], and a start of metabolism from $\mathrm{CO}_{2}$, or autotrophic origins. Volcanos offered an alternative to ponds as a possible site where one could imagine origins, and it led to a different narrative, one that started with surface metabolism, or protobiological reactions in two dimensions before moving to three-dimensional cells [83]. As with the temperature aspect of black smokers, critics honed in on one specific aspect of the theory that seemed particularly vulnerable to criticism-the concept of two-dimensional life [84].

A nuclear geyser. Another setting was suggested by Ebisuzaki and Maruyama [85], a nuclear geyser in which natural radioactive elements provided a great deal of energy in the form of heat and radiation. In the nuclear geyser hypothesis, such sites could provide so much ionizing and thermal energy that organic molecules would easily be generated. This scenario emphasized the energy requirements of early life and that the combination of wetdry cycles should allow molecular concentration and synthesis of more complex organics. Yet, they make no specific proposals for how LUCA emerged from this new setting. In addition, the damaging effects of radiation from intense radioactive decay for biological molecules are well known. Along the same lines, the minimotif synthesis hypothesis [86] does not try to claim how LUCA emerged nor how the primordial soup was created; rather, this hypothesis tries to bridge the gap between the primordial soup and the first evolving RNA world system by creating a scenario of continuously interacting and thus, evolving minimotifs of the first macromolecules.

An RNA world, somewhere. Minimotifs are examples of addressing the origin of one component of a cell. The paradigm for this principle is the RNA world. In the 1960s, many hypotheses involving a seemingly central role of RNA as a simple, possibly selfreproducing component were emerging $[87,88]$. With the recognition that RNA molecules had catalytic activity, the primordial soup hypothesis morphed into an RNA world hypothesis [89,90]. The term "RNA world" itself was coined by Gilbert [91] in the context of Cech's discovery of self-splicing introns [92], with RNA molecules envisaged as recombining in a phase of early evolution of RNA genes preceding the advent of DNA genes. The notion of an "RNA world" quickly gained a much broader meaning in the context of chemical origins however, by incorporating aspects of White's suggestion that coenzymes preceded proteins [93] and the enzyme catalyzed in vitro RNA replication experiments of Eigen from the 1970s [94]. This gave rise to the concept of natural selection among exponentially 
replicating molecules before the advent of natural selection among cells. It is an enticing idea, but it might be wrong [95]. Proponents of the idea that RNA was the starting point of evolution have gone so far as to propose the existence of specific mountainside settings on the early Earth with individual meteorite impacts and a variety of atmosphere-derived cyanide compounds and temperature ranges across hundreds of degrees as Archaean incarnations of chemical reaction conditions that lead to highly specific RNA monomer synthesis in the laboratory [2]. That is, a set of (geochemically quite questionable) Earth conditions are proposed based on the need for their existence in order to accommodate RNA synthesis for the RNA world, creating a curious kind of cart (RNA) and horse (Earth) problem. The early Earth conditions that geochemists infer are not in the slightest conducive to the specific synthesis of RNA bases $[29,96]$ requiring a different early Earth than the one that geochemists have to offer for the RNA world to work. Some researchers question the need for an independent replicator at any point in prebiotic evolution $[97,98]$. Others build entire theories upon the premise of its existence [1], but the question of what natural early Earth setting would accommodate the specific synthesis and operation of a replicator is usually unanswered. Nisbet's proposal of hydrothermal springs to harbor an RNA world [99] with organic synthesis starting from methane and ammonia found little resonance among RNA world proponents. Hydrolysis of RNA has traditionally been seen as an insurmountable problem for hydrothermal vents, and it still is in some circles [21]. Yet it is only a problem if one believes in an RNA world that exists in free aqueous solution, as in typical laboratory experiments, because alkaline hydrothermal vents harbor many local environments of low water activity [8].

$\mathbf{H}_{2}$-producing hydrothermal vents. Deep sea hydrothermal vents that emerge from serpentinizing systems have a chemistry that is fundamentally different from that of black smokers in that their effluent is alkaline and $\sim 100{ }^{\circ} \mathrm{C}$ rather than acidic and $\sim 400{ }^{\circ} \mathrm{C}$. The existence of such alkaline vents on the early Earth was inferred from studies of metal ore deposits $[99,100]$. The first modern deep sea alkaline hydrothermal vent system discovered was the Lost City hydrothermal field [101]. The term alkaline is important because the alkalinity in vents is generated in the process of serpentinization: an unfamiliar word for a philosophy journal but an important one because it produces $\mathrm{H}_{2}$, a well-known currency of chemical energy, in the crust. $\mathrm{H}_{2}$ exits the vent in the effluent; the more alkaline the water is, the more $\mathrm{H}_{2}$ (chemical energy) it contains [102]. The effluent of modern serpentinizing vents contains about four orders of magnitude more $\mathrm{H}_{2}$ than modern $\mathrm{H}_{2}$-dependent microorganisms need to grow. The overall chemistry at alkaline vents shares long overlooked similarity with the main energy harnessing reactions of microbes that live from $\mathrm{H}_{2}$, which can react with $\mathrm{CO}_{2}$ to generate organic compounds spontaneously because the reaction releases energy (it is an exergonic reaction) as recently demonstrated in the laboratory [9]. Alkaline vents continuously synthesize systems of inorganic microcompartments that can concentrate the products of organic synthesis where they are made, offering a means to concentrate the products so that they can react further. The continuous supply of $\mathrm{H}_{2}$ interfacing with inexhaustible reserves of $\mathrm{CO}_{2}$ on the early Earth provides a continuous source of chemical energy to drive the system forward towards higher complexity. In continuity of this reaction, the first cells to emerge from the vent have a carbon and energy metabolism that is based on the exergonic reaction of $\mathrm{H}_{2}$ and $\mathrm{CO}_{2}$, in which the cells synthesize acetate (acetogenic bacteria) or methane (methanogenic archaea) $[4,103,104]$ as the main product of energy metabolism. In that view, the first free living cells were acetogens and methanogens, the starting point from which further physiological evolution took place [11]. This narrative addresses the seven criteria outlined above in a level of explicit detail that others do not; it is compatible with the LUCA inferred from genomic reconstructions [105], while at the same time, connecting the origin of life narrative with real microbial cells that still grow in such environments today.

Variations on a vent. There are variants of the $\mathrm{H}_{2}$-dependent vent narrative for origins. Some replace the chemical energy of the vent with ultraviolet light [106], but the theories do not connect to modern cells because UV light kills cells and no cells can harness energy 
or live from UV light. This generates a hybrid between a pond and a vent, relying on UV light as an energy source like Oparin and Haldane did at a time before anyone knew how cells conserve energy or grow. The hot spring hypothesis [107-109] goes back to the warm little pond, with the settings changed in that the pond is fed by hydrothermal springs (providing thermal energy and wet-dry cycles with first molecules possibly coming from meteorites). There is no chemical role for the vent in the hot spring narrative, it just supplies water and salts, nor is there a connection to the lifestyle of the first cells. Other variants replace the chemical energy of the reaction between $\mathrm{H}_{2}$ and $\mathrm{CO}_{2}$ with chemical energy of the reaction of methane with nitrogen oxides [110], the problem being that in that narrative, the vent is no longer needed because the source of nitrogen oxides is lightning [111], effectively translocating the setting of the vent to the surface, as in the UV model [106] or the hot spring pond. While the $\mathrm{H}_{2}+\mathrm{CO}_{2}$ reaction of the $\mathrm{H}_{2}$ theory produces essential compounds of central metabolism using only hydrothermal catalysts like awaruite or magnetite overnight [9], no similar laboratory reaction is available to which the methane nitrogen oxide narrative could appeal. Other settings include tidal cycles that provided wet-dry cycles [112] for cyclic DNA (or RNA) synthesis. A different hypothesis that relies heavily on the RNA world is the hydrogel hypothesis [113], where the authors explain the stability that was needed for the system to evolve into primordial life by relying on the physicochemical features of a hydrogel. These structures would be similar to today's cytoplasm in retaining its form until cell-like structures with lipid encapsulation could form. This hypothesis proposes that LUCA possibly emerged from a biofilm-like hydrogel formation [114].

\section{Conclusions}

The foregoing provides some examples to underpin the claim in this paper that scientific origins narratives tend to start in a setting, a place that we can imagine. How do those settings connect to the chemical reactions of life? In an earlier passage, we said that trying to find the starting point in the evolution of metabolic pathways is like trying to find a needle in a haystack, but that the problem becomes manageable for one person in one day (given an average sized haystack) if we have a very powerful magnet. One of us has been claiming that we have found that starting point. If so, what was the magnet? The magnet would appear to be physiology: the reactions that cells use to make a living are the reactions that make ATP, which is in turn the molecule whose hydrolysis drives all else in the cell forward (thermodynamics). For very few organisms, the reactions that synthesize ATP are the same reactions that supply carbon to metabolism from $\mathrm{CO}_{2}$ : acetogens and methanogens [11,102-104]. If we look for simple forms of energy metabolism, we find that the simplest ones (anaerobic, $\mathrm{H}_{2}$-dependent, $\mathrm{CO}_{2}$ reducing, using linear pathways instead of cycles, many transition metals as catalysts, lacking cytochromes and quinones hence, older than heme) are similar to naturally occurring exergonic geochemical reactions. When we react $\mathrm{H}_{2}$ with $\mathrm{CO}_{2}$ in the laboratory in water in the presence of a simple hydrothermal mineral as a catalyst - either the pure nickel metal alloy awaruite, the iron oxide magnetite, or the iron sulfide greigite- the backbone of carbon and energy metabolism unfolds all by itself: formate, acetate and pyruvate accumulate in physiologically relevant amounts [9]. All coincidence, possibly, but possibly not.

There is no shortage of settings for origin of life hypotheses and new proposals are constantly emerging. At the most basic level, these fall into two categories with regard to setting: surface or subsurface, with energy coming from the heavens or energy coming from below. This might or might not have a bearing on our unspoken preferences for scientific origins narratives because it would bear rather directly on the possible meaning of origins, facing us with a fairly distinctive choice for what we would rather call our closest relatives among objects of inanimate matter-pointing to the heavens above us or pointing to the Earth beneath us. Genomic reconstructions of LUCA, that is, inferences of the habitat and lifestyle of the last universal ancestor of all cells based on the evidence for 
early life preserved in genomes, recover the physiology of a cell that lived from $\mathrm{H}_{2}, \mathrm{CO}_{2}$, $\mathrm{N}_{2}$, and $\mathrm{H}_{2} \mathrm{~S}$ in a hot metal-rich environment [105].

In the beginning of our solar system, the Earth accreted from remnants of a supernova, so says the planetary narrative. In that sense, our closest relative is stardust from the heavens. We live on the surface. In that sense, our closest relative is the surface. We are buried in the Earth, and when the microbes have had the last word, our carbon becomes $\mathrm{CO}_{2}$ that becomes life of future generations. That was true for our ancestors, in the sense that we come from below. Looking way back, before there was photosynthesis, all life on this planet depended on $\mathrm{H}_{2}$ from serpentinization $[115,116]$. In terms of energy for life, $\mathrm{H}_{2}$ (chemical energy) was the precursor of light (electromagnetic energy). In that sense, our closest inanimate relative would be the reaction of rocks with water in the Earth's crust. Were that so, does it have meaning? Worse, does it have purpose? These are questions that, as a rule, biologists cannot readily answer. However, we can pose them.

In the abstract, we surrendered to the challenge of defining either life or meaning. Greater courage was displayed by Cleland and Chyba [117], who delved into both definitions, concluding that there is no easy definition of life and that the issue regarding the definition of meaning is no simpler, although exploration of both can enrich the way we approach the problems to which these definitions pertain, whereby caution is warranted because many things we now hold to be true as a reference system for definitions might turn out to be false. Cleland [118] later concluded that current approaches to deriving definitions of life are all "deeply flawed". Though not well versed in the long literature of life's definitions, we tend to concur. We furthermore contend that one can study processes relevant to the origin of things that are obviously alive (microbes) and even obtain useful insights into the problem without the strict need for definitions of the process (life) whose origin is under study.

By all accounts, life arose when the Earth was still young. Carbon isotopes indicate the existence of autotrophs by 3.95 [34] or even 4.1 [119] billion years ago, although such studies also point out the possibility that the kind of carbon isotope fractionation found in such ancient samples might be the result of geochemical $\mathrm{H}_{2}$-dependent $\mathrm{CO}_{2}$ reduction rather than the biological process. For proponents of $\mathrm{H}_{2}$-dependent autotrophic origins under hydrothermal conditions, the difference between geochemical and biological $\mathrm{CO}_{2}$ reduction via the most ancient pathway $[9,103]$ boils down to a matter of grade concerning the sophistication of the catalysts.

There is an issue at origins concerning what the Earth "really" looked like $>3.5$ billion years ago when life was already up and running, having already evolved a sulfur-based energy metabolism $[120,121]$. In the least human-friendly versions, the oceans were $10 \mathrm{~km}$ deep because the roughly one (or more) ocean volume of water that is sequestered in the crust and mantle today was still in the ocean [122], meaning that there was no land, a severe problem for some theories about the site of origin. The continents did not form until about 3 billion years ago, long after there was life and they were made of rocks that are very low in silicate content (mafic) meaning that they were particularly prone to generate $\mathrm{H}_{2}$ via serpentinization $[123,124]$. The atmosphere was like that of Venus, mainly $\mathrm{CO}_{2}$ and $\mathrm{N}_{2}$ [29], meaning that the interface of $\mathrm{H}_{2}$-producing vents with a $\mathrm{CO}_{2}$-containing atmosphere and ocean would have generated sites with a good fit to the $\mathrm{H}_{2}$-producing hydrothermal vent idea.

There is also an issue of whether life's origin (less so its meaning) might have something to do with dissipative structures of the kind that Prigogine [125] described. Dissipative structures are discussed in the context of the origin of physicochemical order, as in Zhabotinsky reactions, and in the context of life [126]. Though skeptical that life could be seen as belonging to a category that would fall under the label of dissipative structures, we can say that living cells might have some properties in common dissipative structures, as the latter only arise in far from equilibrium systems, whereby both living things and $\mathrm{H}_{2}$-producing hydrothermal vents are far from equilibrium systems. Dissipative structure or not, what is the source of life's order? It of course depends on who one asks and where 
one thinks how life might have arisen. If life arose from the reaction of $\mathrm{H}_{2}$ and $\mathrm{CO}_{2}$ in hydrothermal vents [103,125], as we contend, then its structure emerges from the geometry of carbon bonds as carbon oxides undergo reduction with electrons and hydrides from $\mathrm{H}_{2}$, reacting to generate longer and more diverse carbon chains [9] while reacting with other elements like nitrogen and sulfur to produce the amino acids, nucleosides, and cofactors that comprise life $[127,128]$, through overall reactions that are thermodynamically favored [129] under the conditions of hydrothermal vents.

In that way, the form and function of molecules of life emerge from the geometry of orbitals in carbon, and the order in cells emerges from the geometry and properties of its molecules as they are synthesized with the help of microbial energy metabolism. That is how life arises today. This order does not conflict with entropy. Measurements of entropy change during growth have repeatedly shown that the entropy change in cells is always zero or close to zero because, "cells are assembled in a spontaneous process" [130]. That is, if a cell has what it needs to grow, it organizes environmentally available components into more of itself as an effortless by-product of the exergonic growth process [103]. The circumstance that central compounds of life arise from $\mathrm{H}_{2}$ and $\mathrm{CO}_{2}$ without enzymes [9] might be taken to mean that that life has a natural tendency to emerge under suitable conditions-but which conditions? We have listed a few of the proposals here. Microbes say: $\mathrm{H}_{2}$-producing hydrothermal vents. Humans have more diverse views. Identifying inanimate matter to which we are most closely related would help us anticipate what to expect, chemically, during the search for life elsewhere-even if it finds us first.

Author Contributions: Conceptualization, A.d.N.V., F.S.P.N., W.F.M.; writing-original draft preparation, final manuscript preparation, A.d.N.V., F.S.P.N., W.F.M.; writing-review and editing, A.d.N.V., F.S.P.N., W.F.M.; revision, W.F.M.; supervision, W.F.M.; funding acquisition, W.F.M. All authors have read and agreed to the published version of the manuscript.

Funding: The authors thank the DFG (Ma 1426/21-1), ERC $(666,053)$, and VW foundation $(93,046$ and 96,742) for funding.

Acknowledgments: We thank Rainer Zimmermann for the kind invitation to submit a paper for this issue and Dan Graur for many stimulating discussions on mutation in the evolutionary process.

Conflicts of Interest: The authors declare no conflict of interest.

\section{References}

1. Kudella, P.W.; Tkachenko, A.V.; Salditt, A.; Maslov, S.; Braun, D. Structured sequences emerge from random pool when replicated by templated ligation. Proc. Natl. Acad. Sci. USA 2021, 118, e2018030118. [CrossRef]

2. Patel, B.H.; Percivalle, C.; Ritson, D.J.; Duffy, C.D.; Sutherland, J.D. Common origins of RNA, protein and lipid precursors in a cyanosulfidic protometabolism. Nat. Chem. 2015, 7, 301-307. [CrossRef]

3. Martin, W.; Russell, M.J. On the origins of cells: A hypothesis for the evolutionary transitions from abiotic geochemistry to chemoautotrophic prokaryotes, and from prokaryotes to nucleated cells. Philos. Trans. R. Soc. Lond. B Biol. Sci. 2003, $358,59-85$. [CrossRef] [PubMed]

4. Martin, W.; Russell, M.J. On the origin of biochemistry at an alkaline hydrothermal vent. Philos. Trans. R. Soc. B Biol. Sci. 2007, 362, 1887-1926. [CrossRef] [PubMed]

5. Priestley, J.; Hey, W. XIX. Observations on different kinds of air. Philos. Trans. R. Soc. Lond. 1772, 62, 147-264. [CrossRef]

6. Krebs, H.A. Otto Heinrich Warburg, 1883-1970. Biogr. Mem. Fellows R. Soc. 1972, 18, 628-699.

7. Höxtermann, E. A comment on Warburg's early understanding of biocatalysis. Photosynth. Res. 2007, 92, 121-127. [CrossRef] [PubMed]

8. Vieira, A.D.N.; Kleinermanns, K.; Martin, W.F.; Preiner, M. The ambivalent role of water at the origins of life. FEBS Lett. 2020, 594, 2717-2733. [CrossRef] [PubMed]

9. Preiner, M.; Igarashi, K.; Muchowska, K.B.; Yu, M.; Varma, S.J.; Kleinermanns, K.; Nobu, M.K.; Kamagata, Y.; Tüysüz, H.; Moran, J.; et al. A hydrogen-dependent geochemical analogue of primordial carbon and energy metabolism. Nat. Ecol. Evol. 2020, 4, 534-542. [CrossRef]

10. Amend, J.P.; Shock, E.L. Energetics of overall metabolic reactions of thermophilic and hyperthermophilic Archaea and Bacteria. Fems Microbiol. Rev. 2001, 25, 175-243. [CrossRef]

11. Martin, W.F. Physiology, phylogeny, and the energetic roots of life. Period. Biol. 2017, 118, 343. [CrossRef]

12. Oparin, A.I. The Origin of Life; Moscow Worker Publisher: Moscow, Russia, 1924. 
13. Darwin, C.R. Darwin Correspondence Project. Available online: https://www.darwinproject.ac.uk/letter/DCP-LETT-7471.xml (accessed on 3 February 2021).

14. Liu, D. The cell and protoplasm as container, object, and substance, 1835-1861. J. Hist. Biol. 2016, 50, 889-925. [CrossRef]

15. Hall, T.S. Ideas of life and matter. Philos. Sci. 1969, 39, 101-102.

16. Geison, G.L. The protoplasmic theory of life and the vitalist-mechanist debate. Isis 1969, 60, 273-292. [CrossRef]

17. Drysdale, G.J.S. The Protoplasmic Theory of Life, 1st ed.; Bailliere, Tindall \& Cox: London, UK, 1874.

18. Kowallik, K.V.; Martin, W.F. The origin of symbiogenesis: An annotated English translation of Mereschkowsky's 1910 paper on the theory of two plasma lineages. Biosystems 2021, 199, 104281. [CrossRef]

19. Madigan, M.T.; Bender, K.S.; Buckley, D.H.; Sattley, M.; Stahl, D.A. Brock Biology of Microorganisms, 15th ed.; Pearson Global Edition: New York, NY, USA, 2019.

20. Haeckel, E. Natürliche Schöpfungs-Geschichte. Gemeinverständliche Wissenschaftliche Vorträge Über Die Entwickelungslehre. Zehnte Verbesserte Auflage. Zweiter Theil: Allgemeine Stammesgeschichte; Georg Reimer: Berlin, Germany, 1902.

21. Marshall, M. How the first life on Earth survived its biggest threat-water. Nature 2020, 588, 210-213. [CrossRef] [PubMed]

22. Miller, S.L. A production of amino acids under possible primitive earth conditions. Science 1953, 117, 528-529. [CrossRef] [PubMed]

23. Haldane, J.B.S. The origin of life. Ration. Annu. 1929, 148, 3-10.

24. Eigen, M.; Gardiner, W.; Schuster, P.; Winkler-Oswatitsch, R. The origin of genetic information. Sci. Am. 1981, 244, 88-118. [CrossRef]

25. Powner, M.W.; Gerland, B.; Sutherland, J.D. Synthesis of activated pyrimidine ribonucleotides in prebiotically plausible conditions. Nat. Cell Biol. 2009, 459, 239-242. [CrossRef]

26. Shapiro, R. Prebiotic cytosine synthesis: A critical analysis and implications for the origin of life. Proc. Natl. Acad. Sci. USA 1999, 96, 4396-4401. [CrossRef]

27. Shapiro, R. Small Molecule Interactions were Central to the Origin of Life. Q. Rev. Biol. 2006, 81, 105-126. [CrossRef] [PubMed]

28. Martin, W.; Baross, J.; Kelley, D.; Russell, M.J. Hydrothermal vents and the origin of life. Nat. Rev. Genet. 2008, 6, 805-814. [CrossRef]

29. Sossi, P.A.; Burnham, A.D.; Badro, J.; Lanzirotti, A.; Newville, M.; O'Neill, H.S. Redox state of Earth's magma ocean and its Venus-like early atmosphere. Sci. Adv. 2020, 6, eabd1387. [CrossRef]

30. Zahnle, K.J.; Lupu, R.; Catling, D.C.; Wogan, N. Creation and evolution of impact-generated reduced atmospheres of early Earth. Planet. Sci. J. 2020, 1, 11. [CrossRef]

31. Mann, A. Cataclysm's end. A popular theory about the early solar system comes under fire. Nature 2018, 553, 393-395. [CrossRef] [PubMed]

32. Smith, E.; Morowitz, H.J. Universality in intermediary metabolism. Proc. Natl. Acad. Sci. USA 2004, 101, 13168-13173. [CrossRef]

33. Abel, P. Evidence for the universality of the genetic code. Cold Spring Harb. Symp. Quant. Biol. 1964, 29, 185-187. [CrossRef]

34. Tashiro, T.; Ishida, A.; Hori, M.; Igisu, M.; Koike, M.; Méjean, P.; Takahata, N.; Sano, Y.; Komiya, T. Early trace of life from 3.95 Ga sedimentary rocks in Labrador, Canada. Nat. Cell Biol. 2017, 549, 516-518. [CrossRef] [PubMed]

35. Schönheit, P.; Buckel, W.; Martin, W.F. On the origin of heterotrophy. Trends Microbiol. 2016, 24, 12-25. [CrossRef]

36. Tempest, D.W.; Neijssel, O.M. The status of YATP and maintenance energy as biologically interpretable phenomena. Annu. Rev. Microbiol. 1984, 38, 459-486. [CrossRef]

37. Russell, J.B. The energy spilling reactions of bacteria and other organisms. J. Mol. Microbiol. Biotechnol. 2007, 13, 1-11. [CrossRef] [PubMed]

38. Bachelard, G. Formation de l'Esprit Scientifique, 5th ed.; Librairie Philosophique J. VRIN: Paris, France, 1934.

39. Herscovics, N.; Linchevski, L. A cognitive gap between arithmetic and algebra. Educ. Stud. Math. 1994, 27, 59-78. [CrossRef]

40. Brousseau, G.; Balacheff, N. Theory of Didactical Situations in Mathematics: Didactique des Mathématiques, 1970-1990, 1st ed.; Springer: Dordrecht, The Netherlands, 1997.

41. Cornu, B. Limits. In Advanced Mathematical Thinking; J.B. Metzler: Dordrecht, The Netherlands, 2002; pp. $153-166$.

42. Mayr, E. What Makes Biology Unique? Considerations on the Autonomy of a Scientific Discipline, 1st ed.; Cambridge University Press: Cambridge, MA, USA, 2005.

43. Mayr, E. The Idea of Teleology. J. Hist. Ideas 1992, 53, 117. [CrossRef]

44. Nei, M. Mutation-Driven Evolution, 1st ed.; Oxford University Press: Oxford, UK, 2013.

45. Whitman, W.B.; Coleman, D.C.; Wiebe, W.J. Prokaryotes: The unseen majority. Proc. Natl. Acad. Sci. USA 1998, 95, 6578-6583. [CrossRef]

46. Hoehler, T.M.; Jørgensen, B.B. Microbial life under extreme energy limitation. Nat. Rev. Genet. 2013, 11, 83-94. [CrossRef]

47. Foster, P.L.; Lee, H.; Popodi, E.; Townes, J.P.; Tang, H. Determinants of spontaneous mutation in the bacterium Escherichia coli as revealed by whole-genome sequencing. Proc. Natl. Acad. Sci. USA 2015, 112, E5990-E5999. [CrossRef]

48. Sprouffske, K.; Aguilar-Rodríguez, J.; Sniegowski, P.; Wagner, A. High mutation rates limit evolutionary adaptation in Escherichia coli. PLoS Genet. 2018, 14, e1007324. [CrossRef]

49. Orgogozo, V. Replaying the tape of life in the twenty-first century. Interface Focus 2015, 5, 20150057. [CrossRef]

50. Bedau, M. Can biological teleology be naturalized? J. Philos. 1991, 88, 647-655. [CrossRef]

51. Wächtershäuser, G. The origin of life and its methodological challenge. J. Theor. Biol. 1997, 187, 483-494. [CrossRef] [PubMed] 
52. Galli, L.M.G.; Meinardi, E.N. the role of teleological thinking in learning the Darwinian model of evolution. Evol. Educ. Outreach 2010, 4, 145-152. [CrossRef]

53. Toepfer, G. Teleology and its constitutive role for biology as the science of organized systems in nature. Stud. Hist. Philos. Sci. Part C Stud. Hist. Philos. Biol. Biomed. Sci. 2012, 43, 113-119. [CrossRef] [PubMed]

54. Ribeiro, M.G.L.; Larentis, A.L.; Caldas, L.A.; Garcia, T.C.; Terra, L.L.; Herbst, M.H.; Almeida, R. On the debate about teleology in biology: The notion of "teleological obstacle". História Ciências Saúde-Manguinhos 2015, 22, 1321-1333. [CrossRef]

55. Bonnin, T. Monist and pluralist approaches on underdetermination: A case study in evolutionary microbiology. J. Gen. Philos. Sci. 2020, 1-21. [CrossRef]

56. Hordijk, W.; Steel, M.; Kauffman, S.A. The structure of autocatalytic sets: Evolvability, enablement, and emergence. Acta Biotheor. 2012, 60, 379-392. [CrossRef]

57. Xavier, J.C.; Hordijk, W.; Kauffman, S.; Steel, M.; Martin, W.F. Autocatalytic chemical networks at the origin of metabolism. Proc. R. Soc. B Biol. Sci. 2020, 287, 20192377. [CrossRef]

58. Muller, H.J. Pilgrim trust lecture-The gene. Proc. R. Soc. Lond. Ser. B Biol. Sci. 1947, 134, 1-37.

59. Oparin, A.I. The Origin of Life on the Earth, 3rd ed.; Academic Press Inc.: New York, NY, USA, 1957.

60. Cairns-Smith, A. The origin of life and the nature of the primitive gene. J. Theor. Biol. 1966, 10, 53-88. [CrossRef]

61. Fox, S.W. A Theory of macromolecular and cellular origins. Nat. Cell Biol. 1965, 205, 328-340. [CrossRef]

62. Bernal, J.D. The Physical Basis of Life, 1st ed.; Routledge and Paul: London, UK, 1951.

63. Sillen, L. Oxidation state of Earths ocean and atmosphere. I. A model calculation on earlier states. Myth of probiotic soup. Ark. Kemi 1965, 24, 431.

64. Hulett, H. Limitations on prebiological synthesis. J. Theor. Biol. 1969, 24, 56-72. [CrossRef]

65. Ross, D.S.; Deamer, D. Dry/wet cycling and the thermodynamics and kinetics of prebiotic polymer synthesis. Life 2016, 6, 28. [CrossRef]

66. Ponnamperuma, C.; Shimoyama, A.; Friebele, E. Clay and the origin of life. Orig. Life Evol. Biosph. 1982, 12, 9-40. [CrossRef] [PubMed]

67. Miller, S.L.; Urey, H.C.; Oró, J. Origin of organic compounds on the primitive earth and in meteorites. J. Mol. Evol. 1976, 9, 59-72. [CrossRef]

68. Kvenvolden, K.A.; Lawless, J.G.; Ponnamperuma, C. Nonprotein amino acids in the Murchison meteorite. Proc. Natl. Acad. Sci. USA 1971, 68, 486-490. [CrossRef]

69. Arrhenius, S. Die Verbreitung des Lebens im Weltenraum. Die Umsch. 1903, 7, 481-485.

70. Weber, P.; Greenberg, J.M. Can spores survive in interstellar space? Nature 1985, 316, 403-407. [CrossRef]

71. Melosh, H.J. The rocky road to panspermia. Nature 1988, 332, 687-688. [CrossRef]

72. Benner, S.A.; Kim, H.-J. The case for a Martian origin for Earth life. In Proceedings of the Instruments, Methods, and Missions for Astrobiology XVII, San Diego, CA, USA, 9-13 August 2015; p. 96060C.

73. Corliss, J.B.; Dymond, J.; Gordon, L.I.; Edmond, J.M.; Von Herzen, R.P.; Ballard, R.D.; Green, K.; Williams, D.; Bainbridge, A.; Crane, K.; et al. Submarine thermal springs on the Galápagos Rift. Science 1979, 203, 1073-1083. [CrossRef]

74. Corliss, J.B.; Baross, J.; Hoffman, S. An hypothesis concerning the relationship between submarine hot springs and the origin of life on Earth. Oceanol. Acta 1981, SP, 59-69.

75. Baross, J.A.; Hoffman, S.E. Submarine hydrothermal vents and associated gradient environments as sites for the origin and evolution of life. Orig. Life Evol. Biosph. 1985, 15, 327-345. [CrossRef]

76. Joyce, G. Hydrothermal vents too hot? Nature 1988, 334, 564. [CrossRef]

77. Nisbet, E.G. Origin of life. Nature 1989, 337, 23. [CrossRef]

78. Brock, T.D.; Isaksen, M.F.; Jannasch, H.W. Life at high temperatures. Science 1985, 230, 132-138. [CrossRef]

79. Kurr, M.; Huber, R.; Jannasch, H.W.; Fricke, H.; Trincone, A.; Kristjansson, J.K.; Stetter, K.O. Methanopyrus kandleri, gen. and sp. nov. represents a novel group of hyperthermophilic methanogens, growing at $110^{\circ} \mathrm{C}$. Arch. Microbiol. 1991, 156, $239-247$. [CrossRef]

80. Maden, B.H. No soup for starters? Autotrophy and the origins of metabolism. Trends Biochem. Sci. 1995, 20, 337-341. [CrossRef]

81. Wächtershäuser, G. Groundworks for an evolutionary biochemistry: The iron-sulphur world. Prog. Biophys. Mol. Biol. 1992, 58, 85-201. [CrossRef]

82. Wächtershäuser, G. Pyrite formation, the first energy source for life: A hypothesis. Syst. Appl. Microbiol. 1988, 10, 207-210. [CrossRef]

83. Wächtershäuser, G. Before enzymes and templates: Theory of surface metabolism. Microbiol. Rev. 1988, 52, 452-484. [CrossRef]

84. De Duve, C.; Miller, S.L. Two-dimensional life? Proc. Natl. Acad. Sci. USA 1991, 88, 10014-10017. [CrossRef]

85. Ebisuzaki, T.; Maruyama, S. Nuclear geyser model of the origin of life: Driving force to promote the synthesis of building blocks of life. Geosci. Front. 2017, 8, 275-298. [CrossRef]

86. Schiller, M.R. The minimotif synthesis hypothesis for the origin of life. J. Transl. Sci. 2016, 2, 289-296. [CrossRef] [PubMed]

87. Crick, F. The origin of the genetic code. J. Mol. Biol. 1968, 38, 367-379. [CrossRef]

88. Orgel, L. Evolution of the genetic apparatus. J. Mol. Biol. 1968, 38, 381-393. [CrossRef]

89. Kruger, K.; Grabowski, P.J.; Zaug, A.J.; Sands, J.; Gottschling, D.E.; Cech, T.R. Self-splicing RNA: Autoexcision and autocyclization of the ribosomal RNA intervening sequence of tetrahymena. Cell 1982, 31, 147-157. [CrossRef] 
90. Pace, N.R.; Marsh, T.L. Rna catalysis and the origin of life. Orig. Life Evol. Biosph. 1985, 16, 97-116. [CrossRef] [PubMed]

91. Gilbert, W. Origin of life: The RNA world. Nature 1986, 319, 618. [CrossRef]

92. Cech, T.R.; Zaug, A.J.; Grabowski, P.J. In vitro splicing of the ribosomal RNA precursor of tetrahymena: Involvement of a guanosine nucleotide in the excision of the intervening sequence. Cell 1981, 27, 487-496. [CrossRef]

93. White, H.B. Coenzymes as fossils of an earlier metabolic state. J. Mol. Evol. 1976, 7, 101-104. [CrossRef] [PubMed]

94. Eigen, M. Selforganization of matter and the evolution of biological macromolecules. Naturwissenschaften 1971, 58, 465-523. [CrossRef]

95. Baross, J.A.; Martin, W.F. The ribofilm as a concept for life's origins. Cell 2015, 162, 13-15. [CrossRef] [PubMed]

96. Zahnle, K.; Arndt, N.; Cockell, C.; Halliday, A.; Nisbet, E.; Selsis, F.; Sleep, N.H. Emergence of a habitable planet. Space Sci. Rev. 2007, 129, 35-78. [CrossRef]

97. Shapiro, R. A replicator was not involved in the origin of life. Iubmb Life 2000, 49, 173-176. [CrossRef]

98. Nisbet, E.G. Origin of life: RNA and hot-water springs. Nature 1986, 322, 206. [CrossRef]

99. Russell, M.J.; Daniel, R.M.; Hall, A.J.; Sherringham, J.A. A hydrothermally precipitated catalytic iron sulphide membrane as a first step toward life. J. Mol. Evol. 1994, 39, 231-243. [CrossRef]

100. Russell, M.J.; Hall, A.J. The emergence of life from iron monosulphide bubbles at a submarine hydrothermal redox and $\mathrm{pH}$ front. J. Geol. Soc. 1997, 154, 377-402. [CrossRef] [PubMed]

101. Kelley, D.S.; Karson, J.A.; Früh-Green, G.L.; Yoerger, D.R.; Shank, T.M.; Butterfield, D.A.; Hayes, J.M.; Schrenk, M.O.; Olson, E.J.; Proskurowski, G.; et al. A serpentinite-hosted ecosystem: The Lost City hydrothermal field. Science 2005, 307, 1428-1434. [CrossRef] [PubMed]

102. Preiner, M.; Xavier, J.C.; Sousa, F.L.; Zimorski, V.; Neubeck, A.; Lang, S.Q.; Greenwell, H.C.; Kleinermanns, K.; Tüysüz, H.; McCollom, T.M.; et al. Serpentinization: Connecting geochemistry, ancient metabolism and industrial hydrogenation. Life 2018, 8, 41. [CrossRef]

103. Martin, W.F. Older than genes: The acetyl CoA pathway and origins. Front. Microbiol. 2020, 11, 817. [CrossRef]

104. Martin, W. On the ancestral state of microbial physiology. In Life Strategies of Microorganisms in the Environment and in Host Organisms; Amann, R., Goebel, W., Schink, B., Widdel, F., Eds.; Wissenschaftliche: Darmstadt, Germany, 2008; Volume 96, pp. 53-60.

105. Weiss, M.C.; Sousa, F.L.; Mrnjavac, N.; Neukirchen, S.; Roettger, M.; Nelson-Sathi, S.; Martin, W.F. The physiology and habitat of the last universal common ancestor. Nat. Microbiol. 2016, 1, 16116. [CrossRef]

106. Mulkidjanian, A.Y.; Bychkov, A.Y.; Dibrova, D.V.; Galperin, M.Y.; Koonin, E.V. Origin of first cells at terrestrial, anoxic geothermal fields. Proc. Natl. Acad. Sci. USA 2012, 109, E821-E830. [CrossRef]

107. Damer, B.; Deamer, D. Coupled phases and combinatorial selection in fluctuating hydrothermal pools: A scenario to guide experimental approaches to the origin of cellular life. Life 2015, 5, 872-887. [CrossRef] [PubMed]

108. Damer, B.; Deamer, D. The hot spring hypothesis for an origin of life. Astrobiology 2020, 20, 429-452. [CrossRef] [PubMed]

109. Longo, A.; Damer, B. Factoring origin of life hypotheses into the search for life in the solar system and beyond. Life 2020, 10, 52. [CrossRef] [PubMed]

110. Nitschke, W.; Russell, M.J. Beating the acetyl coenzyme A-pathway to the origin of life. Philos. Trans. R. Soc. B Biol. Sci. 2013, 368, 20120258. [CrossRef] [PubMed]

111. Ducluzeau, A.-L.; Van Lis, R.; Duval, S.; Schoepp-Cothenet, B.; Russell, M.J.; Nitschke, W. Was nitric oxide the first deep electron sink? Trends Biochem. Sci. 2009, 34, 9-15. [CrossRef]

112. Lathe, R. Fast tidal cycling and the origin of life. Icarus 2004, 168, 18-22. [CrossRef]

113. Trevors, J.T.; Pollack, G.H. Hypothesis: The origin of life in a hydrogel environment. Prog. Biophys. Mol. Biol. 2005, 89, 1-8. [CrossRef]

114. Trevors, J.T. Hypothesized origin of microbial life in a prebiotic gel and the transition to a living biofilm and microbial mats. C. $R$. Biol. 2011, 334, 269-272. [CrossRef]

115. Martin, W.F.; Bryant, D.A.; Beatty, J.T. A physiological perspective on the origin and evolution of photosynthesis. FEMS Microbiol. Rev. 2018, 42, 205-231. [CrossRef] [PubMed]

116. McMahon, S.; Parnell, J. The deep history of Earth's biomass. J. Geol. Soc. 2018, 175, 716-720. [CrossRef]

117. Cleland, C.E.; Chyba, C.F. Does "life" have a definition? In Planets and Life: The Emerging Science of Astrobiology; Sullivan, W.T., Baross, J.A., Eds.; Cambridge University Press: Cambridge, UK, 2007; pp. 119-131.

118. Cleland, C.E. Life without definitions. Synthese 2011, 185, 125-144. [CrossRef]

119. Bell, E.A.; Boehnke, P.; Harrison, T.M.; Mao, W.L. Potentially biogenic carbon preserved in a 4.1 billion-year-old zircon. Proc. Natl. Acad. Sci. USA 2015, 112, 14518-14521. [CrossRef]

120. Wacey, D.; Kilburn, M.R.; Saunders, M.; Cliff, J.; Brasier, M.D. Microfossils of sulphur-metabolizing cells in 3.4-billion-year-old rocks of Western Australia. Nat. Geosci. 2011, 4, 698-702. [CrossRef]

121. Morrison, P.R.; Mojzsis, S.J. Tracing the early emergence of microbial sulfur metabolisms. Geomicrobiol. J. 2020, 38 , 66-86. [CrossRef]

122. Korenaga, J.; Planavsky, N.J.; Evans, D.A.D. Global water cycle and the coevolution of the Earth's interior and sur-face environment. Philos. Trans. R. Soc. A 2017, 375, 20150393. [CrossRef] 
123. Dhuime, B.; Wuestefeld, A.; Hawkesworth, C.J. Emergence of modern continental crust about 3 billion years ago. Nat. Geosci. 2015, 8, 552-555. [CrossRef]

124. Tang, M.; Chen, K.; Rudnick, R.L. Archean upper crust transition from mafic to felsic marks the onset of plate tecton-ics. Science 2016, 351, 372-375. [CrossRef]

125. Prigogine, I. Time, Structure, and Fluctuations. Science 1978, 201, 777-785. [CrossRef]

126. Kondepudi, D.K.; De Bari, B.; Dixon, J.A. Dissipative structures, organisms and evolution. Entropy 2020, 22, 1305. [CrossRef] [PubMed]

127. Martin, W.F. Hydrogen, metals, bifurcating electrons, and proton gradients: The early evolution of biological energy conservation. FEBS Lett. 2012, 586, 485-493. [CrossRef] [PubMed]

128. Wimmer, J.L.E.; Vieira, A.d.N.; Xavier, J.C.; Kleinermanns, K.; Martin, W.F.; Preiner, M. The autotrophic core: An ancient network of 404 reactions converts $\mathrm{H}_{2}, \mathrm{CO}_{2}$, and $\mathrm{NH}_{3}$ into amino acids, bases, and cofactors. Microorganisms 2021, 9, 458. [CrossRef] [PubMed]

129. Amend, J.P.; McCollom, T.M. Energetics of biomolecule synthesis on early Earth. In ACS Symposium Series; American Chemical Society (ACS): Washington, DC, USA, 2010; pp. 63-94.

130. Hansen, L.D.; Criddle, R.S.; Battley, E.H. Biological calorimetry and the thermodynamics of the origination and evo-lution of life. Pure Appl. Chem. 2009, 81, 1843-1855. [CrossRef] 